\title{
Transmembrane Protein 138
}

National Cancer Institute

\section{Source}

National Cancer Institute. Transmembrane Protein 138. NCI Thesaurus. Code C101660.

Transmembrane protein 138 (162 aa, $19 \mathrm{kDa}$ ) is encoded by the human TMEM138 gene. This protein plays a role in the formation of cilium. 